\title{
ResearchArticle
}

\section{Diversity of algae from tahsil Parola, district Jalgaon, Maharashtra}

\author{
RUPALI PATIL, MANISHA SANER AND NEELIMA PATIL
}

\section{SUMMARY}

Biodiversity maintains the ecological balance necessary for human survival. The term biodiversity is commonly used to describe the number, variety and variability of living organism. It forms the foundation for the environmental health of our planet. The present study was undertaken to explore the unexplored area of tahsil Parola, district Jalgaon. Samples were collected from different localities of Parola and analyzed. In the paper an account of diversity of Chlorophyceae and Cyanophyceae was recorded. Fifteen members of Chlorophyceae and fourteen members of Cyanophyceae were observed.

Key Words : Diversity, Algae, Cyanophyceae, Chlorophyceae

How to cite this article : Patil, Rupali, Saner, Manisha and Patil, Neelima (2017). Diversity of algae from tahsil Parola, district Jalgaon, Maharashtra. Internat. J. Plant Sci., 12 (2): 210-215, DOI: 10.15740/HAS/IJPS/12.2/210-215.

Article chronicle : Received : 13.04.2017; Revised : 23.05.2017; Accepted : 11.06.2017

\section{MEMBERS OF THE RESEARCH FORUM}

Author to be contacted :

NEELIMA PATIL, P.G. Department of Botany, JET's, Z.B. Patil College, DHULE (M.S.) INDIA

Email : neelimahp@gmail.com

Address of the Co-authors:

RUPALI PATIL AND MANISHA SANER, P.G. Department of Botany,

JET's, Z.B. Patil College, DHULE (M.S.) INDIA 